Case Report

\title{
Neuroendocrine Tumors: Clinical, Histological and Immunohistochemical Perspectives and Case Report- Mature Teratoma in a 16-Year-Old Girl
}

\author{
Elżbieta Sowińska-Przepiera ${ }^{1,+}{ }^{\text {, Dariusz Starzyński }}{ }^{1,+}{ }^{+}$Anhelli Syrenicz ${ }^{1,+}$, Ireneusz Dziuba $^{2,+}$ (D), \\ Barbara Wiszniewska ${ }^{3,+}$ and Sylwia Rzeszotek ${ }^{3, *,+}$ (D)
}

1 Department of Endocrinology, Metabolic and Internal Diseases, Pomeranian Medical University (PMU), 71-252 Szczecin, Poland; elasowprzep@wp.pl (E.S.-P.); starzynskimd@gmail.com (D.S.); anhelli@asymed.ifg.pl (A.S.)

2 Faculty of Medicine, University of Technology, 40-555 Katowice, Poland; mmid@wp.pl

3 Department of Histology and Embryology, Pomeranian Medical University (PMU), 70-111 Szczecin, Poland; barbara.wiszniewska@pum.edu.pl

* Correspondence: sylwia.rzeszotek@pum.edu.pl

+ All Authors contributed equally to this work.

Citation: Sowińska-Przepiera, E.; Starzyński, D.; Syrenicz, A.; Dziuba, I.; Wiszniewska, B.; Rzeszotek, S Neuroendocrine Tumors: Clinical, Histological and

Immunohistochemical Perspectives and Case Report-Mature Teratoma in a 16-Year-Old Girl. Pathophysiology 2021, 28, 373-386. https://doi.org/ 10.3390 /pathophysiology28030025

Academic Editor: Jonathan

Steven Alexander

Received: 22 July 2021

Accepted: 25 August 2021

Published: 27 August 2021

Publisher's Note: MDPI stays neutral with regard to jurisdictional claims in published maps and institutional affiliations.

Copyright: (c) 2021 by the authors. Licensee MDPI, Basel, Switzerland. This article is an open access article distributed under the terms and conditions of the Creative Commons Attribution (CC BY) license (https:/ / creativecommons.org/licenses/by/ $4.0 /)$.

\begin{abstract}
A mature teratoma is a germinal neoplasm that differentiates from embryonic multipotent cells into three germ layers. There may also be glandular tissue. The literature describes a total of 658 cases of ovarian neuroendocrine neoplasms, mainly in women over 40 years of age. The authors, together with a systemic review, present a case of a 16-year-old girl diagnosed with and treated for a neuroendocrine tumor. Case description: A 16-year-old girl visited the Paediatric Gynaecology Outpatient Clinic because of abdominal pains that intensified during menstruation. Standard painkillers and diastolic drugs were ineffective. An ultrasound examination revealed a large tumor with a heterogeneous structure in her right ovary. A sparing operation was carried out. During laparotomy, the lesion was enucleated, leaving healthy tissue. Histopathological examination revealed the typical features of teratoma, as well as the coexistence of a G1 neuroendocrine tumor. Immunohistochemical examination (IHC) showed the presence of markers characteristic for this type of tumor. The patient requires constant monitoring in the Endocrinology and Oncological Gynaecology Clinic. Conclusion: Tissue of neuroendocrine neoplasm within a teratoma is rare in this age group of patients; thus, there are currently no standards for long-term follow-up. This case adds to the body of evidence and demonstrates a possible good prognosis with non-aggressive behavior in G1 neuroendocrine tumors and teratomas in young patients.
\end{abstract}

Keywords: germinal neoplasm; neuroendocrine tumor; ovarian tumor; pediatric gynecology; teratoma; IHC

\section{Introduction}

Primary germ cell (PGC) migration and their invasion of the genital ridges directs the development of the indifferent gonads into a testis or ovary, as well as differentiation of the germ cells. Aberrations during this process can lead to the appearance of germ cells anywhere, usually in the midline location, which is one of the steps in the PGC migration pathway from the yolk sac [1,2]. Ectopic germ cells can cause benign and malignant neoplasms-germ cell tumors (GCT) [3].

Teratomas are a common form of GCT. They can arise congenitally or can develop in childhood; in addition, especially with regard to gonadal teratomas, they develop over the course of life. However, most cases are seen in people in their reproductive years [4]. Mature cystic teratoma (MCT) occurs in 10-20\% of all ovarian cancers, and the average age of occurrence is perimenopausal $[5,6]$. MCT in pure form is benign; however, it may also undergo a malignant change in any of its somatic elements [7]. 
The tissue of mature teratomas may be glandular, the most common being that of the thyroid gland, the so-called ovarian goiter, which occurs in approximately $3-5 \%$ of teratomas [8].

Neuroendocrine tumors (NETs) are considered rare in the general population, with an estimated incidence of 4-8 cases per 100,000 people, both in clinical observations and in post-mortem studies [9]. NETs are a heterogeneous group of neoplasms that arise from cells of the endocrine and nervous systems and can be functional or non-functional [10-12]. In recent decades, the incidence of these rare tumors has increased significantly, and their malignant potential (NETs were previously considered relatively benign) has been reported $[13,14]$. However, this upward trend may be due to improved diagnostics and a standardized classification system $[15,16]$.

Ovary neuroendocrine (tumors) neoplasms (oNETs) account for approximately $0.3 \%$ of gonadal tumors [17]. oNETs differ morphologically, including poorly differentiated variants and well-differentiated low-grade variants called carcinoids [18]. Dispersed neuroendocrine cells can give rise to neuroendocrine tumors in all tissue types also in combination with teratoma. Primary ovarian carcinoid tumors are extremely rare, usually appear in perimenopausal women and their behavior is poorly predictable.

In around $75 \%$ of cases, oNETs occur unilaterally as a component of a mature teratoma. In approximately $15 \%$ of cases, they occur bilaterally in the form of a cyst, mucinous or Brenner tumor [19].

In $25-30 \%$ of cases, NETs may be associated with carcinoid syndrome, which means that they release biologically active substances into the blood. The symptoms of carcinoid syndrome depend mainly on the substance released from the cancer cells into the blood. [20]. The paroxysmal nature of the symptoms is characteristic, and they include face and neck redness, tachycardia, dizziness, excessive sweating, diarrhea, watery stools with accompanying abdominal pain, weight loss and symptoms of bronchospasm, such as dyspnea and wheezing. Carcinoid syndrome is especially common in tumors of the ileum and jejunum, but it can also occur in NETs of the bronchi, ovaries and other tumor locations. In the gut, the symptoms of carcinoid syndrome are usually seen in people with advanced disease who have metastatic foci in the liver; however, in the bronchial localization, they may occur earlier since the peptides secreted by the tumor are not degraded in the liver [21,22].

In this case, NET was present as a histological component of a teratoma and was hormonally inactive in a 16-year-old patient.

\section{Case Presentation}

Written and signed informed consent was obtained from the patient. A 16-year-old female patient came to the clinic due to intensified pain during menstruation. She used painkillers, mainly paracetamol, which were ineffective. The patient had been menstruating for 3 years. She did not report chronic diseases or prior surgeries. The physical examination showed normal somatic gender development (according to Tanner Th4P4A4 scale) adequate for her age.

Routine ultrasound examination revealed the presence of a large, heterogeneous tumor $(14.0 \times 10.0 \times 10.5 \mathrm{~cm})$ in the right ovary. Standard laboratory tests showed no abnormalities. The concentrations of germinal ( $\alpha$-fetoprotein, AFP; human chorionic gonadotropin, hCG; lactate dehydrogenase, LDH) and epithelial (CA-125 tumor antigen, CA-125; carcinoembryonic antigen, CEA) tumor markers were within the normal ranges. Computed tomography (CT) and subsequent nuclear magnetic resonance (NMR) revealed a large $(15 \times 13 \times 9 \mathrm{~cm})$, non-homogeneous, encapsulated tumor in the projection of the right ovary. There were no signs of infiltration or enlargement of the lymph nodes. The remaining genital structures, including the left ovary, were unaffected (Figure 1).

Due to the patient's young age, a sparing laparotomy was performed. The tumor of the right ovary, a periapical cyst and $5 \mathrm{~mL}$ of fluid from the abdominal cavity were removed. No postoperative complications occurred. 


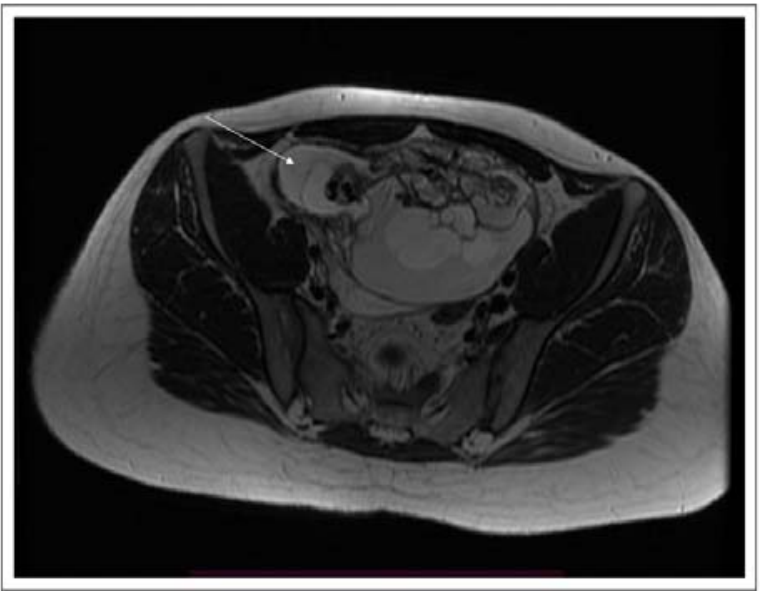

Figure 1. NMR of the pelvis minor in the transverse plane. The arrow indicates the tumor in the right ovary.

Histopathological examinations reveled a mature cystic teratoma with a G1 neuroendocrine neoplasm focus; immunohistochemical (IHC) analysis revealed approximately $1 \%$ Ki-67 and synaptophysin-positive (Syp) areas, while chromogranin A (CgA) was weak with a "dot-like" cytoplasmic pattern. Additionally, cytokeratin 19 (CK19), neural cell adhesion molecule (CD56) and neuron-specific enolase (NSE) were positive in many tests (please check Supplementary Materials). In the abdominal cavity, no tumor cells were found.

Due to the presence of tissue with NET features, the patient's case was presented to a team of experts to determine further management and monitoring of oncological treatment.

It was recommended to monitor the patient for the development of carcinoid syndrome and to determine the concentration of NET tumor activity markers: chromogranin A and 5-hydroxyindole acetic acid (5-HIAA).

The patient's clinical symptoms as well as biochemical and imaging results are presented in Table 1.

Table 1. Clinical symptoms and results of consecutive biochemical and imaging diagnostic steps performed after operation in a 16-year-old girl with an ovarian neuroendocrine tumor after operation.

\begin{tabular}{ccc}
\hline Symptoms of Carcinoid Syndrome & Absent \\
\hline Tumor marker concentrations & Chromogranin A & $\begin{array}{c}28.21 \mathrm{ug} / \mathrm{L} \\
\text { (normal: 0-100 ug/L) }\end{array}$ \\
\cline { 2 - 3 } & $* * 5-\mathrm{HIAA}-\mathrm{mg} / 24 \mathrm{~h}$ & $\begin{array}{c}18.85 \mathrm{mg} / 24 \mathrm{~h} \\
\text { (normal: } 2-6 \mathrm{mg} / 24 \mathrm{~h})\end{array}$ \\
\hline
\end{tabular}

Pelvic computed tomography (CT) A $2.0 \times 3.5 \mathrm{~cm}$ mass adjacent to the posterior wall of the uterus, slightly strengthening after the administration of contrast (postoperative lesions and the left part of the ovary)

\begin{tabular}{|c|c|}
\hline Tc99 receptor scintigraphy & No somatostatin receptor expression \\
\hline * PET/CT GAL68 & $\begin{array}{l}\text { Lack of somatostatin receptor expression in the operated area. A small focal point with } \\
\text { increased receptor expression in pineal topography }\end{array}$ \\
\hline $\begin{array}{l}\text { Magnetic resonance } \\
\text { imaging (MRI) }\end{array}$ & $\begin{array}{c}\text { Pineal topography showed an oval structure measuring } 11 \times 10 \times 9 \mathrm{~mm} \\
\text { with features of a cyst }\end{array}$ \\
\hline
\end{tabular}

Pelvic ultrasonography (USG) of the pelvis minor

Vague picture in the right appendage projection

MRI of the pelvis minor

No lesions suspected of being cancerous were found

* PET/CT GAL68-positron emission tomography with somatostatin analogue labeled with gallium isotope (68Ga-DOTA-peptide);

** 5-HIAA-5-hydroxyindoleacetic acid. 
An elevated 5-HIAA concentration was found (18.85 mg/24 h; normal: 2-6 mg/24 h), which may suggest the presence of local foci or cancer metastases. Preoperative diagnostics did not indicate a hormonally active neuroendocrine tumor due to the lack of typical clinical symptoms of carcinoid syndrome, so preoperative 5HIAA determination in $24 \mathrm{~h}$ urine collection was not performed. On the other hand, postoperative 5HIAA determination in $24 \mathrm{~h}$ urine collection suggests incomplete removal of the ovarian tumor from NET, NET foci with a different location or metastatic changes. However, imaging diagnostics using MR, PET/CT with Ga68 and receptor scintigraphy did not reveal changes confirming this suspicion, which requires further observation and control. The concentration was measured according to the current rules in order to exclude false-positive results [20]. Chromogranin A was within the normal range (28.21 ug/L; normal: 0-100 ug/L).

CT scans were performed to compare the pre- and post-surgery conditions, followed by technetium (Tc)-99m receptor scintigraphy, which did not detect pathological foci showing increased expression of the somatostatin receptor. The positron emission tomography/computed tomography (PET/CT) examination with Gallium-68 DOTATATE (68 Ga-DOTATATE) radiotracer revealed a small focal point with increased somatostatin receptor expression in pineal topography. NMR imaging was recommended, which showed a cystic structure in this area (Figure 2).

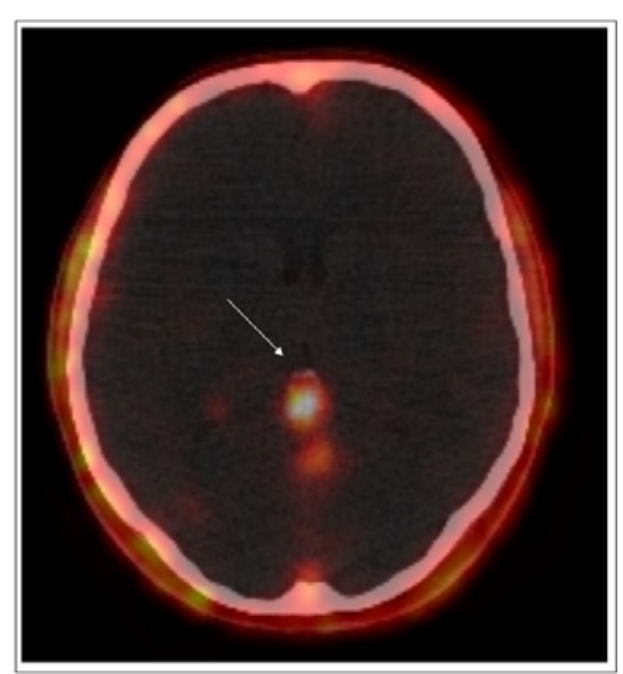

Figure 2. PET/CT test (68Ga-DOTA-peptide). The arrow indicates the increased somatostatin receptor expression in the pineal gland.

Pelvic sonography and NMR showed no additional tumor foci or metastases. The oncological diagnostics have been completed at this stage. The patient is currently under constant supervision.

\section{Methods}

IHC

The dissected tumor was fixed with $10 \%$ formalin for at least $24 \mathrm{~h}$ and then washed with absolute ethanol, absolute ethanol with xylene (1:1) and xylene. Then, after the tissues were saturated with liquid paraffin, the samples were embedded in paraffin blocks. Using a microtome (Microm HM340E, Walldorf, Germany), serial 3-5 $\mu \mathrm{m}$ sections were taken and placed on poly-l-lysine-coated microscope slides (Thermo Scientific, Leicestershire, UK; Cat. No. J2800AMNZ). The sections were deparaffinized in xylene and rehydrated in decreasing ethanol concentrations before being used for H\&E and IHC staining. To reveal epitopes for IHC, the sections were boiled twice in Target Retrieval Solution (DakoCytomation, Glostrup, Denmark; S2367, S2369) in a microwave oven (700 W, twice for $5 \mathrm{~min}$ ). After cooling and washing with PBS, endogenous peroxidase was blocked with a $3 \%$ perhydrol solution in methanol; then, slides were incubated overnight at $4{ }^{\circ} \mathrm{C}$ with primary antibodies 
against: Ki-67 (Dako Agilent, Santa Clara, CA, USA; GA626, ready to use), synaptophysin (Syp, Dako Agilent, Santa Clara, CA, USA; GA660, ready to use), cytokeratin CK19 (CK19, Dako Agilent, Santa Clara, CA, USA; GA615 ready to use), neural cell adhesion molecule (CD56, Dako Agilent, Santa Clara, CA, USA; M7304, final concentration 1:200), CD34 molecule (CD34, Dako Agilent, Santa Clara, CA, USA; GA632, ready to use), platelet endothelial cell adhesion molecule (CD31, Dako Agilent, Santa Clara, CA, USA; GA610, ready to use), podoplanin D2-40 (D2-40, Dako Agilent, Santa Clara, CA, USA; M3619, final concentration 1:200), thyroid transcription factor 1 (TTF-1, Dako Agilent, Santa Clara, CA, USA; M3575, final concentration 1:200), (CK20, Dako Agilent, Santa Clara, CA, USA; M7019, final concentration 1:200), homeobox protein CDX-2 (CDX2, Dako Agilent, Santa Clara, CA, USA; M3636, final concentration 1:200), thyroglobulin (Tg, Dako Agilent, Santa Clara, CA, USA; M0781, final concentration 1:200), calcitonin (CT, Dako Agilent, Santa Clara, CA, USA; A0576, final concentration 1:200), chromogranin A (CgA, Dako Agilent, Santa Clara, CA, USA; M0869, final concentration 1:200), neuron-specific enolase (NSE, Dako Agilent, Santa Clara, CA, USA; M0873, final concentration 1:200), glial fibrillary acidic protein (GFAP, Dako Agilent, Santa Clara, CA, USA; Z0334, final concentration 1:200).

Antibodies were diluted in Antibody Diluent if required (Dako Agilent, Santa Clara, CA, USA; S3022). To visualize the antigen-antibody complex, a Dako LSAB+SystemHRP was used (DakoCytomation, Glostrup, Denmark; K0679), based on the reaction of avidin-biotin-horseradish peroxidase with $\mathrm{DAB}$ as a chromogen, according to the included staining procedure instructions. Sections were washed in distilled $\mathrm{H}_{2} \mathrm{O}$ and counterstained with hematoxylin. For a negative control, specimens were processed in the absence of a primary antibody. Positive staining was determined microscopically (Leica DM5000B, Wetzlar, Germany) by visual identification of brown pigmentation.

\section{Results}

\subsection{Histopathological Findings}

The tumor mass, with a size of $13 \times 10 \times 8 \mathrm{~cm}$, on a multicystic cross-section, was loose, due to the predominance of fat and sebum (tallow), and filled with hairs, teeth and mucogelatinous content.

\subsubsection{TERATOMA}

Microscopic examination of the ovary tumor revealed tissues derived from mesenchyme, mesoderm, endoderm, ectoderm and neuroectoderm. Mature hyaline cartilage encapsuled partially with connective tissue, occasionally with bone trabeculae, and some components of the epiphyseal plate were identified. Scattered islands of mucous and serous glands were present, especially in the area of epithelium typical for the bronchi. The cells of the bone marrow were the only population within this tumor showing the expression of Ki-67 (Figure 3A). Irregular lymphoid nodules and the accumulation of lymphocytes were present in the connective tissue of the mucosa of the alimentary tract. The mucosa was lined with different types of epithelia. Most of the secretory gland-like structures were not accompanied by ducts. The most abundant tissue type in this ovarian teratoma was skin with pilosebaceous units. There was the coexistence of rounded or arched cords of columnar or pyramidal cells typical for the glomerulosa zone of the adrenal cortex (Figure 3B) and thyroid gland. Thyrocytes with a tendency to form follicular structures showed variability in shape - cuboidal, flattened or even slightly columnar-and were located around the colloid (Figure 3C). They showed no malignant features similar to pleomorphic and anaplastic cells. However, in some cells, cytoplasm was scanty and pale with large nuclei with dense chromatin and invisible nucleoli, and, in the others, the nucleus was typically vesicular with visible nucleoli. Signet ring cells were invisible. There was no evidence of proliferation, solid growth of the tumor cells or necrosis. Glandular structures lined with cuboidal or columnar epithelial cells with bright cytoplasm and flattened nuclei were noticeable. Structures were separated by a delicate fibrovascular tissue. 


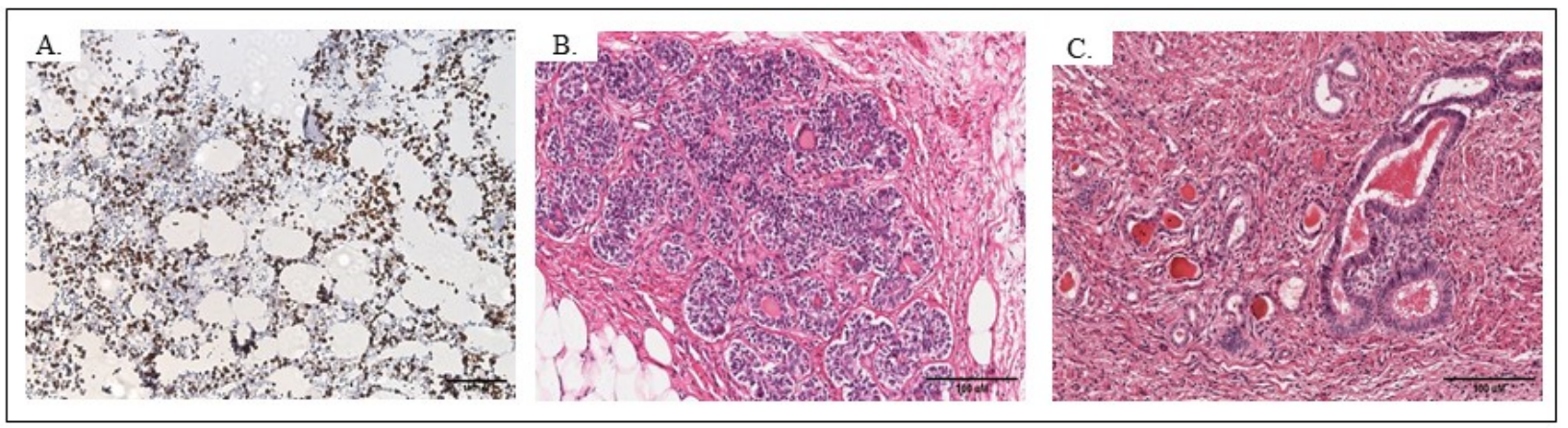

Figure 3. HE staining of the strumal carcinoid of the ovary, objective magn. $\times 20$, Leica DM5000B, Wetzlar, Germany. Ki-67 expression was limited to the bone marrow area of the teratoma (A); rounded or arched cords of columnar or pyramidal cells typical for the glomerulosa zone of the adrenal cortex were visible within the strumal carcinoid (B); thyrocytes with variability in shape-cuboidal, flattened or even slightly columnar-were observed surrounding the colloid (C).

\subsubsection{NET}

Within the teratoma, small, round cells with coarse, salt and pepper nuclear chromatin were observed. Morphological findings indicated that a carcinoid tumor was present in the wall of the mature cystic teratoma. The architecture of the NET was rather glandular. Tumor cells were arranged in acini and trabeculae, having round to oval nuclei, stippled chromatin and abundant granular eosinophilic cytoplasm. Other elements of this teratoma with co-occurrence of a G1 neuroendocrine tumor resembled a heavily disturbed tissue type without sufficient distinguishable characteristic features.

\subsection{Immunohistochemical Findings of NET}

Syp was expressed in the cells of the NET (Figure 4). Cells of the tumor were negative for CK20, CDX2 and Tg. A positive signal was observed only in some cells of the carcinoid for CK19 and CD56. The areas associated with NET included blood vessels and lymphatic vessels, which were evaluated with CD34, CD31 and podoplanin D2-40. Within the area of thyroid tissue, a negative signal for CT and Tg and positive for TTF1 was identified, accompanied by a strong positive reaction for markers of the endothelium of the blood and lymphatic vessels. 

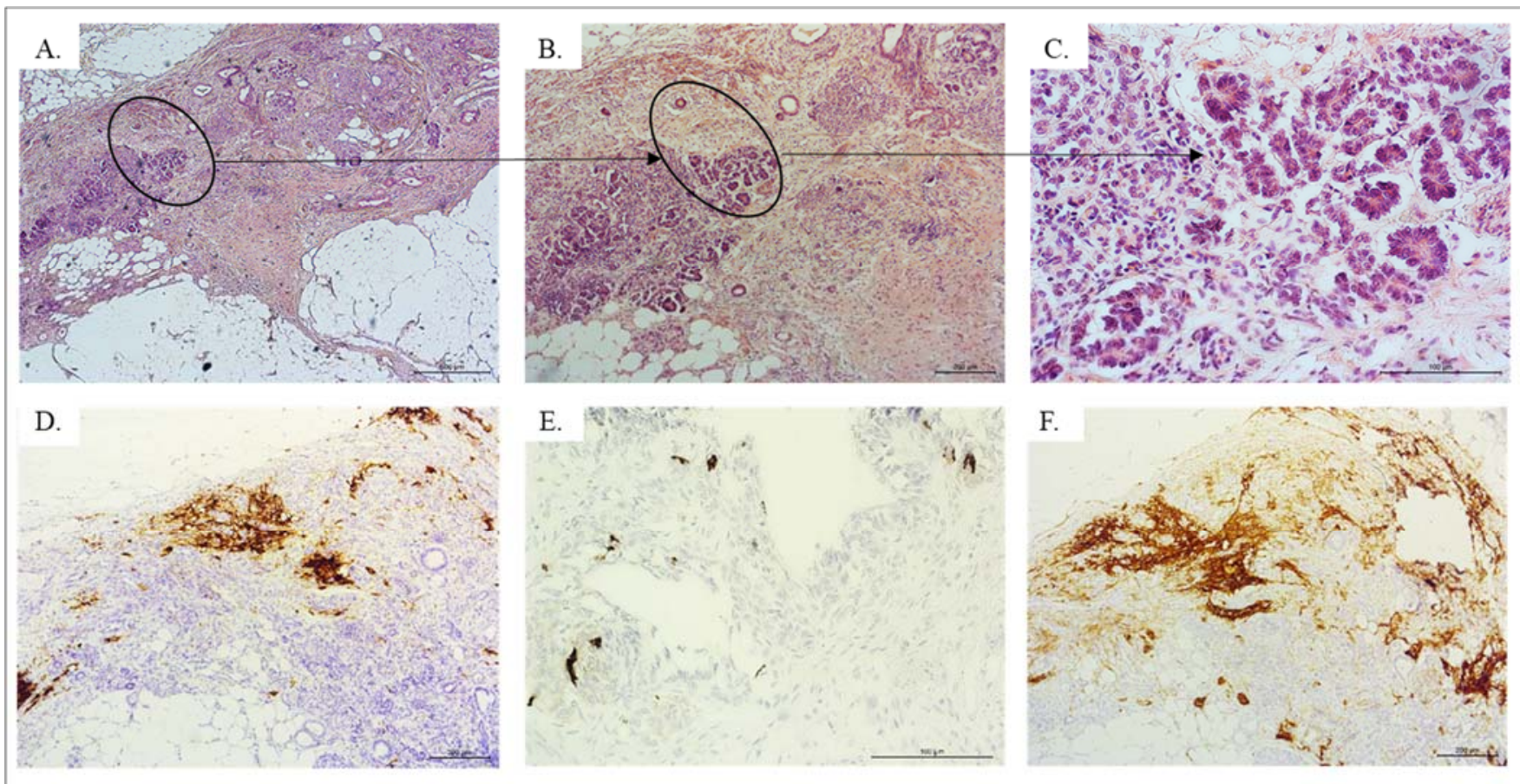

Figure 4. HE and IHC staining of the NET, Leica DM5000B, Wetzlar, Germany. Localization of the NET within the teratoma: ((A). objective magn. $\times 5$; (B). objective magn. $\times 20$; (C). objective magn. $\times 40)$; Syp in cells of the NET $((\mathbf{D})$. objective magn. $\times 20)$; CgA was weak, with "dot-like" cytoplasmic pattern $((\mathbf{E})$. objective magn. $\times 40)$, CD56 positive area $((\mathbf{F})$. objective magn. $\times 20)$.

\subsection{Immunohistochemical Findings of Teratoma}

Vascular proliferations identified with high expression of CD34 (Figure 5B) and CD31 (Figure 5C) positive cells were observed within the strumal area. Bundles of the nerve fibers were common. Occasionally, areas with neural differentiation positive for GFAP (Figure 5A) and reaching blood vessels were visible.
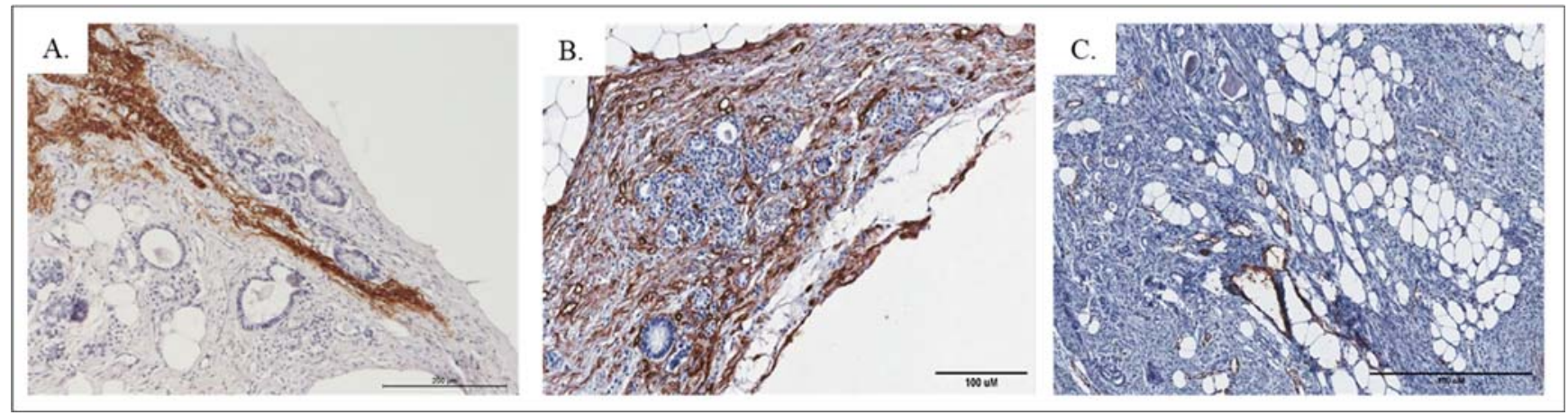

Figure 5. Area of carcinoid with GFAP ((A). objective magn. $\times 20)$, CD $34((\mathbf{B})$. objective magn. $\times 10)$ and CD31 ((C). objective magn. $\times 10)$.

\section{Discussion}

NET

The teratoma diagnosed in this patient with NET tissue is extremely rare in this age group (Table 2); thus, there are no standards for long-term follow-up. Preoperative differentiation of benign and malignant changes in the ovary in young premenopausal women is difficult because no test or algorithm is clear about the accuracy and differentiation of these changes. The exceptions are embryonic tumors with elevated levels of specific 
tumor markers such as $\alpha$-FP or hCG. In addition, approximately $10 \%$ of ovarian lesions are suspected to be metastatic and not of ovarian origin [23]. The diagnosis of an ovarian proliferative lesion (hyperplasia) exceeding $6 \mathrm{~cm}$ in premenopausal women is an indication for diagnostics and surgical treatment as the possibility of a malignant process should be considered [24]. In young women before their peri-reproductive period, as in our patient, if technically possible, surgery should be performed using the least invasive technique, i.e., laparoscopy. However, after a comprehensive surgical evaluation, the surgical technique should be carefully chosen. The preoperative assessment of malignant potential is necessary to plan the optimal surgical strategy $[25,26]$.

Primary and secondary ovarian NETs have similar histological growth mechanisms but differ in clinical course, treatment and prognosis [27].

A previous analysis of 329 oNET cases showed that if these tumors are not a component of teratomas, they tend to be larger in size and have more frequent general and liver metastases and a lower 5-year survival rate [19].

$\mathrm{Ki}-67$ is an independent prognostic biomarker for patients. The Ki-67 value is determined by immunohistochemical methods with mindbomb homolog 1 (MIB1) antibody; the number of mitotic figures is also evaluated. According to the current WHO 2019 [28] classification, neuroendocrine neoplasms (NENs) are divided into highly differentiated NET G1 with Ki-76 < 3\%, NET G2 with Ki-67 of 3-20\%, NET G3 with Ki-67 > 20\%; low differentiated neuroendocrine carcinomas (NECs) with Ki-67 > 20\%; microcellular (SCNEC) or giant cell (LCNEC); and mixed neuroendocrine neoplasms (MiNEN) with a variable Ki-67 proliferative index. In this case, this proliferation indicator was identified only within the area of the bone marrow and did not align with the high number of CD31- and CD34positive cells. It is worth noting as the stage of vascular maturity can be an important differentiating factor in teratoma grading criteria [29]. In predictions, attention should be paid to vascular invasion and infiltration of the capsule [30].

CT produced primarily by the parafollicular cells (C-cells) can also be an IHC marker for the metastatic medullary thyroid carcinoma. In this case, we did not find a positive signal for CT. The relationship between functionally inactive (negative for $\mathrm{Tg}, \mathrm{CT}$ and intermediate expression of TTF1) thyroid tissue and a neuroendocrine marker-secreting tumor present within the teratoma can be connected to the theory of the stem cell origin of this kind of tumor. The clinically silent thyroid tissue observed within this teratoma could be connected to improper migration, aberrant differentiation or, as some authors report, transport of the thyroid cells through the lymphatic vessels. It was challenging to clearly differentiate some features: follicles were heterogeneous in shape and a tissue pattern was unclear, with pleomorphic nuclei and, in some areas, crowded nuclei. However, cellular proliferation was invisible and the majority of the tissue had cells that were regular in shape [31].

In this case, expression of CK19 was observed in the lining of the alimentary tract but there was no evidence of cellular proliferation in this area. This is important as, in some carcinomas, high co-expression of CK19 and Ki-67 is an undesirable prognostic marker [32].

In this case, the focus of the highly mature neuroendocrine carcinoid was identified with a Syp, weak CgA, negative CK20 and positive CD56. Synaptophysin as a specific marker for neuroendocrine tumors showed cytoplasmic authoritative results. The combined use of CK19 and CD56 is helpful in discriminating papillary thyroid carcinoma and its variants from other mimicking thyroid lesions [33]. We did not find co-expression of these markers in the area of the thyroid tissue.

Podoplanin is a protein expressed in a variety of cell types, but the positive reaction with podoplanin D2-40 antibody is a known marker of the lymphatic vessels and their development [34]. In the studied case, D2-40 was visible as typical membranous, strong and diffuse staining in lymphatic vessels, but it was also present at the periphery of the sebaceous glands and in the deeper parts of the stratified squamous epithelium, limiting the tumor. The role of podoplanin in tumor invasion is under discussion; however, it has 
been observed that podoplanin is upregulated in the outer edge of the tumor mass and, in some cases, is associated with poor prognosis [35].

Our patient had a G1-type oNET in combination with dermoid, without carcinoid syndrome, which appears to be prognostically favorable. In long-term observation, limited and mainly casuistic data concerning the proliferation index in the prediction of oNETs have been reported [36].

According to the recommendations of the Polish Network of Neuroendocrine Tumors, surgery is the main method for the treatment of oNET. In the case of G1-type tumors, a joint ovariectomy-tumor excision is recommended, with the excision of the uterus with adnexa and a larger network for malignant tumors [36].

The European Society of Medical Oncology (ESMO) guidelines for non-epithelial neoplasms advise that young patients undergo sparing treatment to preserve fertility. Fertility-saving surgeries seem to be safe, with excellent survival after long-term follow-up, such as the inclusion of more aggressive treatments. Patients with stage IA G1 teratomas do not require neoadjuvant chemotherapy. Chemotherapy in more advanced stages (IA G2-G3, IB-IC) is controversial. Patients who have abandoned chemotherapy should be actively monitored. In the case of oNET teratoma, specialist imaging tests are recommended, e.g., $\mathrm{PET} / \mathrm{CT}, \mathrm{CT}$, receptor scintigraphy, MRI and assessment of the concentrations of markers specific for these types of tumors [37]. oNETs co-occurring with teratomas are characterized by good prognosis, rare metastases and symptoms of carcinoid syndrome; however, due to the lack of long-term observations of these rare cases, the National Comprehensive Cancer Network guidelines do not cover oNETs (www.nccn.org, version 2.2021, accessed on 24 August 2021).

Table 2. Age of patients described in case reports of carcinoids.

\begin{tabular}{|c|c|c|c|}
\hline Year & Author & Diagnosis & Age \\
\hline 2020 & Maccora et al. [38] & mature teratoma with insular carcinoid tumor of the ovary & 68 \\
\hline 2019 & Chai et al. [39] & strumal carcinoid tumor of the ovary & 63 \\
\hline 2019 & Yan et al. [40] & multiple endocrine neoplasia type 1-related atypical ovarian carcinoid & 30 \\
\hline 2019 & Borghese et al. [41] & $\begin{array}{c}\text { bilateral MCT with foci of ovarian strumal carcinoid, } \\
\text { developed lymph node para aortic metastasis after } 30 \text { years from primary } \\
\text { diagnosis }\end{array}$ & $?$ \\
\hline 2019 & Hsu et al. [42] & primary ovarian mucinous carcinoid tumor, atypical type, very aggressive & 33 \\
\hline 2018 & Ishida et al. [43] & stromal carcinoid of the ovary & 68 \\
\hline 2018 & Macháleková et al. [44] & stromal carcinoid of the ovary & 46,52 \\
\hline 2018 & Niu et al. [45] & $\begin{array}{l}\text { carcinoid arising from the teratomatous bronchial mucosa in an ovarian } \\
\text { MCT }\end{array}$ & 22 \\
\hline 2017 & Fiore et al. [46] & goblet-cell carcinoid of the ovary & 18 \\
\hline 2016 & Kim [47] & carcinoid tumor of the trabecular type arising from an MCT in ovary & 25 \\
\hline 2016 & Erdenebaatar et al. [48] & insular carcinoid tumor of the ovary with a trabecular component & 70 \\
\hline 2016 & Kim et al. [49] & $\begin{array}{l}\text { primary ovarian mixed strumal and mucinous carcinoid arising in an } \\
\text { ovarian MCT }\end{array}$ & 39 \\
\hline 2016 & Vora et al. [17] & $\begin{array}{l}\text { well-differentiated carcinoid tumor with no surface epithelial involvement, } \\
\text { and a mature teratoma in the contralateral ovary, } \\
\text { a mature teratoma; } \\
\text { strumal carcinoid within the ovarian parenchyma; } \\
\text { poorly differentiated carcinoma with neuroendocrine differentiation }\end{array}$ & $\begin{array}{r}40 \\
26 \\
63,32\end{array}$ \\
\hline 2015 & Kim et al. [50] & $\begin{array}{l}\text { primary ovarian carcinoid tumor with loss of neuroendocrine growth } \\
\text { pattern, increased mitotic activity and large areas of coagulative tumor } \\
\text { necrosis, atypical carcinoid }\end{array}$ & 21 \\
\hline
\end{tabular}


Table 2. Cont.

\begin{tabular}{|c|c|c|c|}
\hline Year & Author & Diagnosis & Age \\
\hline 2015 & Mieczkowska et al. [51] & $\begin{array}{l}\text { primary ovarian carcinoid in mature teratoma of one ovary, co-existing } \\
\text { with primary epithelial carcinoma of another ovary }\end{array}$ & \\
\hline 2015 & Târcoveanu et al. [52] & ovarian strumal carcinoid and cystic lymphangioma & 55 \\
\hline 2015 & Muller et al. [53] & ovarian strumal carcinoid (peptide YY producing) & 34 \\
\hline 2014 & Goldman et al. [54] & $\begin{array}{l}\text { secondary to carcinoid heart disease caused by a primary ovarian carcinoid } \\
\text { tumor }\end{array}$ & 61 \\
\hline 2014 & Gupta et al. [55] & primary ovarian carcinoid tumor simulating virilizing tumor of the ovary & 62 \\
\hline 2014 & Kumar et al. [56] & carcinoid of the ovary & 53 \\
\hline 2013 & Sulaiman et al. [57] & strumal carcinoid tumor stage $1 \mathrm{~A}$ of the ovary & 30 \\
\hline 2012 & Takatori et al. [58] & strumal carcinoid of the ovary (peptide YY producing) & 48 \\
\hline 2013 & Hayashi et al. [59] & primary strumal carcinoid tumor of the ovary & 45 \\
\hline 2011 & Takeuchi et al. [60] & $\begin{array}{l}\text { strumal carcinoid tumor of the ovary } \\
\text { primary strumal carcinoid tumor of the ovary }\end{array}$ & $\begin{array}{l}72 \\
77\end{array}$ \\
\hline 2011 & Matsunami et al. [61] & strumal carcinoid tumor of the ovary (peptide YY producing) & 45 \\
\hline 2010 & Marcy et al. [62] & lethal, malignant, metastatic struma ovarii & 45 \\
\hline 2010 & Bai et al. [63] & primary ovarian trabecular carcinoid tumor & 55 \\
\hline 2010 & Kurabayashi et al. [64] & $\begin{array}{l}\text { primary strumal carcinoid tumor of the ovary with multiple bone and } \\
\text { breast metastases }\end{array}$ & 34 \\
\hline 2009 & Suneja et al. [65] & primary malignant melanoma in cystic teratoma of ovary & 50 \\
\hline 2009 & Guney et al. [66] & primary carcinoid tumor arising in a mature cystic teratoma & 54 \\
\hline 2009 & Gungor et al. [67] & primary ovarian carcinoid arising from a mature cystic teratoma & 47 \\
\hline 2008 & Lagoudianakis et al. [68] & primary ovarian insular carcinoid tumor & 44 \\
\hline 2008 & Gorin \& Sastre-Garau [69] & strumal carcinoid tumor of the ovary & 63 \\
\hline 2007 & Somak et al. [70] & primary carcinoid tumor of the ovary & 55 \\
\hline 2007 & Morken et al. [71] & primary ovarian carcinoid tumor & 70 \\
\hline 2006 & Chatzipantelis et al. [72] & $\begin{array}{l}\text { insular carcinoid and mucinous cystadenoma of low malignant potential, } \\
\text { arising in a cystic teratoma }\end{array}$ & 57 \\
\hline 2006 & Karavolos et al. [73] & primary mucinous carcinoid tumor of the ovary & 34 \\
\hline 2005 & Kopf et al. [74] & primary carcinoid tumor of the ovary & 79 \\
\hline 2003 & Kuscu et al. [75] & ovarian carcinoid stage IA & 47 \\
\hline 2002 & Matsuda et al. [76] & strumal carcinoid tumor of the ovary (peptide YY producing) & 50 \\
\hline 2000 & McMurray [77] & $\begin{array}{l}\text { benign left ovarian cystic teratoma, and a right carcinoid tumor of the } \\
\text { ovary }\end{array}$ & 57 \\
\hline 1996 & Kasantikul et al. [78] & primary ovarian carcinoid (insular, trabecular and mucinous components) & 53 \\
\hline 1996 & Chou et al. [79] & primary ovarian carcinoid tumor & 25 \\
\hline 1995 & Takemori et al. [80] & $\begin{array}{l}\text { ovarian strumal carcinoid in association with dermoid cyst and mucinous } \\
\text { cystadenoma in the same ovary }\end{array}$ & 54 \\
\hline 1995 & Yaegashi et al. [81] & primary trabecular carcinoid of the ovary & 43 \\
\hline 1993 & Kataoka et al. [82] & $\begin{array}{l}\text { trabecular carcinoid tumor associated intimately with thyroid follicle-like } \\
\text { structures, strumal carcinoid arising in a benign cystic teratoma }\end{array}$ & 41 \\
\hline 1992 & Erhan et al. [83] & primary carcinoid tumor & 55 \\
\hline
\end{tabular}




\section{Conclusions}

The described pathology, extremely rare in this age group, was diagnosed by histopathological examination. Due to the young age of the patient and the need to preserve fertility, sparing surgery was applied. Using Tg as the only marker of thyroid tissue can create challenges. Long-term observation of these casuistic reports will allow for possible verification of the applied treatment. Nowadays, with the opportunity to evaluate and personalize the treatment of the patient, it is crucial to identify markers and pay attention to malignant transformations of initially not disturbing changes. It is encouraging that there is an increasing number of better described IHC markers that allow for diagnosis and the estimation of risk and prognosis. Unfortunately, NETs in the ovary are rare, so many predictive markers are based on observations of NETs present in the gastrointestinal tract. The stage of vascular proliferation and maturity is an important factor in tumor development and progression and should be carefully evaluated. This case adds to the body of evidence and demonstrates a possible good prognosis with non-aggressive behavior.

Supplementary Materials: The following are available online at https://www.mdpi.com/article/10 .3390 / pathophysiology28030025/s1, Figure S1: IHC staining of the NET within the teratoma, Leica DM5000B, Wetzlar, Germany. Top row: negative signal for: A. CT $\times 20, \mathrm{~B}$. Tg $\times 20, \mathrm{C}$. CDX-2 $\times 20, \mathrm{D}$. CK-20 x40. Bottom row: positive signal for: E. CK-19 $\times 20$, F. TTF- $1 \times 20$, G. podoplaninD2-40 $\times 40 \mathrm{H}$. NSE $\times 20$.

Author Contributions: Conceptualization: E.S.-P., D.S., S.R.; Contributed essential reagents: I.D.; Substantive support: I.D., A.S., B.W.; Data curation: S.R., E.S.-P.; Formal analysis: S.R., D.S.; Investigation: S.R., B.W., D.S., A.S.; Writing and original figures: S.R., D.S.; Writing and review and editing: S.R., B.W., D.S. All authors have read and agreed to the published version of the manuscript.

Funding: The performing of the research, the publishing and the English editing of the publication were financed by funds for research and development (statutory activity of the Pomeranian Medical University in Szczecin, WMS-167-02/S/16/2020).

Institutional Review Board Statement: Not applicable.

Informed Consent Statement: Written informed consent has been obtained from the Patient to publish this paper.

Data Availability Statement: The data presented in this study are available on request from the corresponding author. The data are not publicly available due to Patient's privacy.

Acknowledgments: We would like to express our special thanks to the Students' Research Organization at the Department of Endocrinology, Metabolic Disorders and Internal Diseases of Pomeranian Medical University. In particular, we thank Abramczyk U., Salloum D., Jakubowski D., Jędrzejczyk A. and Czernecka J. for their commitment to popularizing the results.

Conflicts of Interest: The authors declare no conflict of interest.

\section{References}

1. Nikolic, A.; Volarevic, V.; Armstrong, L.; Lako, M.; Stojkovic, M. Primordial Germ Cells: Current Knowledge and Perspectives. Stem Cells Int. 2016, 2016, 1741072. [CrossRef]

2. Kolasa, A.; Misiakiewicz, K.; Marchlewicz, M.; Wiszniewska, B. The generation of spermatogonial stem cells and spermatogonia in mammals. Reprod. Biol. 2012, 12, 5-23. [CrossRef]

3. Pierce, J.L.; Frazier, A.L.; Amatruda, J.F. Pediatric Germ Cell Tumors: A Developmental Perspective. Adv. Urol. 2018, 2018, 9059382. [CrossRef]

4. Stella, F; Davoli, F. Giant mediastinal mature teratoma with increased exocrine pancreatic activity presenting in a young woman: A case report. J. Med. Case Rep. 2011, 5, 238. [CrossRef] [PubMed]

5. Shaaban, A.M.; Rezvani, M.; Elsayes, K.M.; Baskin, H., Jr.; Mourad, A.; Foster, B.R.; Jarboe, E.A.; Menias, C.O. Ovarian malignant germ cell tumors: Cellular classification and clinical and imaging features. Radiographics 2014, 34, 777-801. [CrossRef]

6. Shanthi, E.; Parimala, A.; Chander, R.V.; Jayashree, K.; Sulochana, S. Ovarian struma-Report of a rare case. J. Clin. Diagn. Res. 2015, 9, QJ01. [CrossRef] [PubMed]

7. Rathore, R.; Sharma, S.; Agarwal, S. Malignant transformation in mature cystic teratoma of the ovary: A retrospective study of eight cases and review of literature. Menop. Rev. 2018, 17, 63-68. [CrossRef] [PubMed] 
8. Deshpande, H.; Balkawade, N.; Gore, C.; Deshpande, A. Struma ovarii: A rare case report. Int. J. Pharm. Biomed. Sci. 2012, 3, 152-154.

9. Chauhan, A.; Yu, Q.; Ray, N.; Farooqui, Z.; Huang, B.; Durbin, E.B.; Tucker, T.; Evers, M.; Arnold, S.; Anthony, L.B. Global burden of neuroendocrine tumors and changing incidence in Kentucky. Oncotarget 2018, 9, 19245-19254. [CrossRef]

10. Kulke, M.H.; Mayer, R.J. Carcinoid tumors. N. Engl. J. Med. 1999, 340, 858-868. [CrossRef]

11. Estrozi, B.; Bacchi, C.E. Neuroendocrine tumors involving the gastroenteropancreatic tract: A clinicopathological evaluation of 773 cases. Clinics 2011, 66, 1671-1675.

12. Oronsky, B.; Ma, P.C.; Morgensztern, D.; Carter, C.A. Nothing But NET: A Review of Neuroendocrine Tumors and Carcinomas. Neoplasia 2017, 19, 991-1002. [CrossRef]

13. Rindi, G.; Petrone, G.; Inzani, F. The 2010 WHO classification of digestive neuroendocrine neoplasms: A critical appraisal four years after its introduction. Endocr. Pathol. 2014, 25, 186-192. [CrossRef] [PubMed]

14. Klimstra, D.S. Pathologic Classification of Neuroendocrine Neoplasms. Hematol. Clin. N. Am. 2016, 30, 1-19. [CrossRef]

15. Rouzbahman, M.; Clarke, B. Neuroendocrine tumors of the gynecologic tract: Select topics. Semin. Diagn. Pathol. 2013, 30, 224-233. [CrossRef] [PubMed]

16. Gardner, G.J.; Reidy-Lagunes, D.; Gehrig, P.A. Neuroendocrine tumors of the gynecologic tract: A Society of Gynecologic Oncology (SGO) clinical document. Gynecol. Oncol. 2011, 122, 190-198. [CrossRef] [PubMed]

17. Vora, M.; Lacour, R.A.; Black, D.R.; Turbat-Herrera, E.A.; Gu, X. Neuroendocrine tumors in the ovary: Histogenesis, pathologic differentiation, and clinical presentation. Arch. Gynecol. Obstet. 2016, 293, 659-665. [CrossRef]

18. Metwally, I.H.; Elalfy, A.F.; Awny, S.; Elzahaby, I.A.; Abdelghani, R.M. Primary ovarian carcinoid: A report of two cases and a decade registry. J. Egypt. Natl. Cancer Inst. 2016, 28, 267-275. [CrossRef] [PubMed]

19. Soga, J.; Osaka, M.; Yakuwa, Y. Carcinoids of the ovary: An analysis of 329 reported cases. J. Exp. Clin. Cancer Res. 2000, 19, 271-280.

20. Feldman, J.M.; Lee, E.M. Serotonin content of foods: Effect on urinary excretion of 5-hydroxyindoleacetic acid. Am. J. Clin. Nutr. 1985, 42, 639-643. [CrossRef]

21. Oleinikov, K.; Avniel-Polak, S.; Gross, D.J.; Grozinsky-Glasberg, S. Carcinoid Syndrome: Updates and Review of Current Therapy. Curr. Treat. Options Oncol. 2019, 20, 70. [CrossRef]

22. Davis, Z.; Moertel, C.G.; McIlrath, D.C. The malignant carcinoid syndrome. Surg. Gynecol. Obstet. 1973, 137, 637-644.

23. Royal College of Obstetricians and Gynaecologists. Management of suspected ovarian masses in premenopausal women. In Green-Top Guideline; RCOG: London, UK, 2011.

24. Spaczyński, M.; Bidziński, M.; Basta, A.; Dańska-Bidzińska, A.; Breborowicz, G.H.; Emerich, J.; Grabiec, M.; Kedzia, W.; Kornafel, J.; Kotarski, J.; et al. Polish Gynecological Society's recommendations regarding ovarian cancer. Ginekol. Pol. $2006,77,495-501$.

25. Chen, R.F.; Li, J.; Zhu, T.T.; Yu, H.L.; Lu, X. Fertility-sparing surgery for young patients with borderline ovarian tumors (BOTs): Single institution experience. J. Ovarian Res. 2016, 9, 16. [CrossRef] [PubMed]

26. Renaud, E.J.; Sømme, S.; Islam, S.; Cameron, D.B.; Gates, R.L.; Williams, R.F.; Jancelewicz, T.; Oyetunji, T.A.; Grabowski, J.; Diefenbach, K.A.; et al. Ovarian masses in the child and adolescent: An American Pediatric Surgical Association Outcomes and Evidence-Based Practice Committee systematic review. J. Pediatr. Surg. 2019, 54, 369-377. [CrossRef] [PubMed]

27. Kos-Kudła, B.; Blicharz-Dorniak, J.; Strzelczyk, J.; Bałdys-Waligórska, A.; Bednarczuk, T.; Bolanowski, M.; Boratyn-Nowicka, A.; Borowska, M.; Cichocki, A.; Ćwikła, J.B.; et al. Diagnostic and therapeutic guidelines for gastro-entero-pancreatic neuroendocrine neoplasms (recommended by the Polish Network of Neuroendocrine Tumours). Endokrynol. Pol. 2017, 68, 79-110. [CrossRef] [PubMed]

28. Nagtegaal, I.D.; Odze, R.D.; Klimstra, D.; Paradis, V.; Rugge, M.; Schirmacher, P.; Washington, K.M.; Carneiro, F.; Cree, I.A. The 2019 WHO classification of tumours of the digestive system. Histopathology 2020, 76, 182-188. [CrossRef] [PubMed]

29. Hongo-Kohama, M.; Kurata, A.; Hashimoto, H.; Fujita, K.; Horiuchi, H.; Nagao, T.; Kuroda, M. Vascular Smooth Muscle Cell Maturation Stage and Ki-67 Index are Diagnostic Biomarkers for Pathologic Grade of Ovarian Teratoma. Int. J. Gynecol. Pathol. 2017, 36, 582-592. [CrossRef] [PubMed]

30. Wreesmann, V.B.; Nixon, I.J.; Rivera, M.; Katabi, N.; Palmer, F.; Ganly, I.; Shaha, A.R.; Tuttle, R.M.; Shah, J.P.; Patel, S.G.; et al. Prognostic value of vascular invasion in well-differentiated papillary thyroid carcinoma. Thyroid 2015, 25, 503-508. [CrossRef]

31. Cappello, F.; Barbato, F.; Tomasino, R.M. Mature teratoma of the uterine corpus with thyroid differentiation. Pathol. Int. 2000, 50, 546-548. [CrossRef]

32. Ernst, J.; Ikenberg, K.; Apel, B.; Schumann, D.M.; Huber, G.; Studer, G.; Rordorf, T.; Riesterer, O.; Rössle, M.; Korol, D.; et al. Expression of CK19 is an independent predictor of negative outcome for patients with squamous cell carcinoma of the tongue. Oncotarget 2016, 7, 76151-76158. [CrossRef] [PubMed]

33. Abouhashem, N.S.; Talaat, S.M. Diagnostic utility of CK19 and CD56 in the differentiation of thyroid papillary carcinoma from its mimics. Pathol. Res. Pract. 2017, 213, 509-517. [CrossRef] [PubMed]

34. Gomaa, A.H.; Yaar, M.; Bhawan, J. Cutaneous immunoreactivity of D2-40 antibody beyond the lymphatics. Am. J. Dermatopathol. 2007, 29, 18-21. [CrossRef] [PubMed]

35. Martin, A.L.; Jolliffe, E.; Hertweck, S.P. Ovarian Teratoma Associated with Coexisting Anti-N-Methyl-D-Aspartate Receptor and Glial Fibrillary Acidic Protein Autoimmune Meningoencephalitis in an Adolescent Girl: A Case Report. J. Pediatr. Adolesc. Gynecol. 2018, 31, 321-324. [CrossRef] [PubMed] 
36. Zhang, X.; Jones, A.; Jenkins, S.M.; Huang, Y. Ki67 Proliferative Index in Carcinoid Tumors Involving Ovary. Endocr. Pathol. 2018, 29, 43-48. [CrossRef] [PubMed]

37. Ray-Coquard, I.; Morice, P.; Lorusso, D.; Prat, J.; Oaknin, A.; Pautier, P.; Colombo, N. Non-epithelial ovarian cancer: ESMO Clinical Practice Guidelines for diagnosis, treatment and follow-up. Ann. Oncol. 2018, 29 (Suppl. S4), iv1-iv18. [CrossRef]

38. Maccora, D.; Caldarella, C.; Leombroni, M.; De Stefano, V.; Leccisotti, L. Incidental Finding of an Ovarian Carcinoid on 11C-Methionine PET/CT. Clin. Nucl. Med. 2020, 45, e483-e485. [CrossRef]

39. Chai, W.; Zhang, W.; Zhou, L.; Sun, X.; Jia, G. Strumal carcinoid tumor of the ovary: A rare case report. Medicine 2019, 98 , e18009. [CrossRef]

40. Yan, B.; Wang, Y.; Zhang, Y.; Lou, W. Teratoma-associated anti-N-methyl-D-aspartate receptor encephalitis: A case report and literature review. Medicine 2019, 98, e15765. [CrossRef]

41. Borghese, M.; Razzore, P.; Ferrero, A.; Daniele, L.; Mariani, L.L.; Sgro, L.G.; De Rosa, G.; Biglia, N. Metastatic Bilateral Strumal Carcinoid: A Case Report and Review of the Literature. Anticancer Res. 2019, 39, 5053-5056. [CrossRef]

42. Hsu, W.W.; Mao, T.L.; Chen, C.H. Primary ovarian mucinous carcinoid tumor: A case report and review of literature. Taiwan. J. Obstet. Gynecol. 2019, 58, 570-573. [CrossRef]

43. Ishida, M.; Arimoto, T.; Sandoh, K.; Okano, K.; Ebisu, Y.; Ito, H.; Matsumoto, M.; Mizokami, T.; Kita, M.; Okada, H.; et al. Imprint cytology of strumal carcinoid of the ovary: A case report with immunocytochemical analysis. Diagn. Cytopathol. 2019, 47, 218-221. [CrossRef]

44. Macháleková, K.; Kolníková, G.; Redecha, M.; Žúbor, P.; Kajo, K. Strumal carcinoid of the ovary-Report of two cases and review of literature. Ceska Gynekol. 2018, 83, 452-457. [PubMed]

45. Niu, D.; Li, Z.; Sun, L.; Cao, D. Carcinoid Arising From the Teratomatous Bronchial Mucosa in a Mature Cystic Teratoma of the Ovary: A Case Report. Int. J. Gynecol. Pathol. 2018, 37, 123-127. [CrossRef]

46. Fiore, M.G.; Rossi, R.; Covelli, C.; Loizzi, V.; Piscitelli, D.; Cormio, G. Goblet-cell carcinoid of the ovary: A case report with ultrastructural analysis. J. Obstet. Gynaecol. 2017, 37, 266-267. [CrossRef]

47. Kim, S.A.; Kwon, Y.; Kim, S.; Joung, H. Assessment of Dietary Mercury Intake and Blood Mercury Levels in the Korean Population: Results from the Korean National Environmental Health Survey 2012-2014. Int. J. Environ. Res. Public Health 2016, 13, 877. [CrossRef]

48. Erdenebaatar, C.; Yamaguchi, M.; Saito, F.; Motooka, C.; Tashiro, H.; Katabuchi, H. An Ovarian Carcinoid Tumor with Peptide YY-Positive Insular Component: A Case Report and Review of the Literature. Int. J. Gynecol. Pathol. 2016, 35, 362-368. [CrossRef] [PubMed]

49. Kim, N.R.; Ha, S.Y.; Shin, J.W.; Lim, S.; Park, C.Y.; Cho, H.Y. Primary ovarian mixed strumal and mucinous carcinoid arising in an ovarian mature cystic teratoma. J. Obstet. Gynaecol. Res. 2016, 42, 211-216. [CrossRef]

50. Kim, H.S.; Yoon, G.; Jang, H.I.; Song, S.Y.; Kim, B.G. Primary ovarian carcinoid tumor showing unusual histology and nuclear accumulation of $\beta$-catenin. Int. J. Clin. Exp. Pathol. 2015, 8, 5749-5752. [PubMed]

51. Mieczkowska, E.; Marciniak, A.; Szydłowska, I.; Brodowska, A.; Starczewski, A. Rare case of coexistence of primary ovarian carcinoid in mature teratoma with primary serous carcinoma in second ovary-A case report. Eur. J. Gynaecol. Oncol. 2015, 36, 330-332.

52. Târcoveanu, E.; Vasilescu, A.; Fotea, V.; Ciobanu, D.; Crumpei, F.; Bradea, C. Rare Tumors, Rare Association: Ovarian Strumal Carcinoid-Retroperitoneal Cystic Lymphangioma. Chirurgia 2015, 110, 294-299.

53. Muller, K.E.; Tafe, L.J.; Gonzalez, J.L.; West, L.A.; Schned, A.R. Ovarian strumal carcinoid producing peptide YY associated with severe constipation: A case report and review of the literature. Int. J. Gynecol. Pathol. 2015, 34, 30-35. [CrossRef] [PubMed]

54. Goldman, T.; Adamson, K.; Yang, E. Resolution of right-sided heart failure symptoms after resection of a primary ovarian carcinoid tumor. Tex. Heart Inst. J. 2014, 41, 533-536. [CrossRef]

55. Gupta, B.; Suneja, A.; Vaid, N.B.; Bhatia, A. Primary ovarian carcinoid tumor simulating virilizing tumor of the ovary: A rare entity. Indian J. Cancer 2014, 51, 529. [CrossRef] [PubMed]

56. Kumar, M.; Rajwanshi, A.; Dey, P. Carcinoid of the ovary: Diagnostic challenge on fine-needle aspiration cytology. Diagn. Cytopathol. 2014, 42, 612-614. [CrossRef]

57. Sulaiman, S.; Chia, Y.N.; Namuduri, R.V. Strumal carcinoid tumour of the ovary presenting with severe constipation. Singapore Med. J. 2013, 54, e21-e23. [PubMed]

58. Takatori, E.; Shoji, T.; Miura, J.; Takeuchi, S.; Yoshizaki, A.; Sugiyama, T. Case of peptide-YY-producing strumal carcinoid of the ovary: A case report and review. J. Obstet. Gynaecol. Res. 2012, 38, 1266-1270. [CrossRef]

59. Hayashi, T.; Haba, R.; Kushida, Y.; Kadota, K.; Katsuki, N.; Miyai, Y.; Shibuya, S.; Sasaki, M.; Bando, K.; Matsunaga, T.; et al. Cytopathologic characteristics of the primary strumal carcinoid tumor of the ovary: A case report with emphasis on differential diagnostic considerations. Diagn. Cytopathol. 2013, 41, 812-816. [CrossRef]

60. Takeuchi, M.; Matsuzaki, K.; Uehara, H. Primary carcinoid tumor of the ovary: MR imaging characteristics with pathologic correlation. Magn. Reson. Med. Sci. 2011, 10, 205-209. [CrossRef]

61. Matsunami, K.; Takagi, H.; Ichigo, S.; Murase, T.; Ikeda, T.; Imai, A. Peptide YY producing strumal carcinoid tumor of the ovary. Eur. J. Gynaecol. Oncol. 2011, 32, 201-202.

62. Marcy, P.Y.; Thariat, J.; Benisvy, D.; Azuar, P. Lethal, malignant, metastatic struma ovarii. Thyroid 2010, 20, 1037-1040. [CrossRef] 
63. Bai, X.; Li, N.; Wang, F.; Li, S.; Yu, Q. Primary ovarian trabecular carcinoid tumor: A case report and literature review. Arch. Gynecol. Obstet. 2010, 282, 407-411. [CrossRef] [PubMed]

64. Kurabayashi, T.; Minamikawa, T.; Nishijima, S.; Tsuneki, I.; Tamura, M.; Yanase, T.; Hashidate, H.; Shibuya, H.; Motoyama, T. Primary strumal carcinoid tumor of the ovary with multiple bone and breast metastases. J. Obstet. Gynaecol. Res. 2010, 36, 567-571. [CrossRef]

65. Suneja, A.; Yadav, P.; Sharma, A.; Vaid, N.B.; Singh, B.; Grover, R.K. Primary malignant melanoma in cystic teratoma of ovary. Indian J. Cancer 2009, 46, 340. [CrossRef] [PubMed]

66. Guney, N.; Sayilgan, T.; Derin, D.; Ozcan, D. Primary carcinoid tumor arising in a mature cystic teratoma of the ovary: A case report. Eur. J. Gynaecol. Oncol. 2009, 30, 223-225. [PubMed]

67. Gungor, T.; Altinkaya, O.; Ozat, M.; Sirvan, L.; Yalcin, H.; Mollamahmutoglu, L. Primary adenocarcinoid tumor of the ovary arising in mature cystic teratoma. A case report. Eur. J. Gynaecol. Oncol. 2009, 30, 110-112.

68. Lagoudianakis, E.E.; Markogiannakis, H.; Karantzikos, G.; Papadima, A.; Alevizos, L.; Manouras, A. Primary insular carcinoid of the ovary. Eur. J. Gynaecol. Oncol. 2008, 29, 554-555. [PubMed]

69. Gorin, I.; Sastre-Garau, X. Strumal carcinoid tumor of the ovary. J. Clin. Oncol. 2008, 26, 2780-2781. [CrossRef] [PubMed]

70. Somak, R.; Shramana, M.; Vijay, S.; Nita, K. Primary carcinoid tumor of the ovary: A case report. Arch. Gynecol. Obstet. 2008, 277, 79-82. [CrossRef] [PubMed]

71. Morken, N.H.; Majak, B.; Kahn, J.A. Insulin producing primary ovarian carcinoid tumor. Acta Obstet. Gynecol. Scand. 2007, 86, 500-501. [CrossRef]

72. Chatzipantelis, P.; Mavrogiorgis, A.; Kairi-Vassilatou, E.; Pafiti, A. Ovarian neoplasm composed of an insular carcinoid tumor and a borderline mucinous cystadenoma arising in a mature cystic teratoma: A case report. Eur. J. Gynaecol. Oncol. 2006, 27, 636-637. [PubMed]

73. Karavolos, S.; Caplin, M.; Benjamin, E.; Crow, J.; Mould, T. Primary mucinous carcinoid tumour of the ovary: A case report. Eur. J. Gynaecol. Oncol. 2006, 27, 618-620. [PubMed]

74. Kopf, B.; Rosti, G.; Lanzanova, G.; Marangolo, M. Locally advanced ovarian carcinoid. J. Exp. Clin. Cancer Res. 2005, 24, 313-316. [PubMed]

75. Kuscu, E.; Eroglu, D.; Ozdemir, B.H.; Secme, S.; Haberal, A. Primary carcinoid tumor of the ovary: A case report. Eur. J. Gynaecol. Oncol. 2003, 24, 574-576.

76. Matsuda, K.; Maehama, T.; Kanazawa, K. Strumal carcinoid tumor of the ovary: A case exhibiting severe constipation associated with PYY. Gynecol. Oncol. 2002, 87, 143-145. [CrossRef] [PubMed]

77. McMurray, J.E. A case of diarrhea and orthopnea in a 57-year-old female. WMJ 2000, 99, 25-28, 34.

78. Kasantikul, V.; Triratanachart, S.; Maneesri, S.; Panichabhongse, V. Primary ovarian carcinoid: A mixture of insular, trabecular and mucinous components. J. Med. Assoc. Thai. 1996, 79, 200-204.

79. Chou, Y.Y.; Shun, C.T.; Huang, S.C.; Chuang, S.M. Primary ovarian carcinoid tumor. J. Formos. Med. Assoc. 1996, 95, 148-152.

80. Takemori, M.; Nishimura, R.; Sugimura, K.; Obayashi, C.; Yasuda, D. Ovarian strumal carcinoid with markedly high serum levels of tumor markers. Gynecol. Oncol. 1995, 58, 266-269. [CrossRef]

81. Yaegashi, N.; Tsuiki, A.; Shimizu, T.; Kobayashi, N.; Sato, S.; Namiki, T.; Motoyama, T.; Katayama, Y.; Yajima, A. Ovarian carcinoid with severe constipation due to peptide YY production. Gynecol. Oncol. 1995, 56, 302-306. [CrossRef]

82. Kataoka, A.; Nishida, T.; Sugiyama, T.; Ohta, S.; Tomita, J.; Yakushiji, M. Strumal carcinoid of the ovary. Kurume Med. J. 1993, 40, 49-52. [CrossRef] [PubMed]

83. Erhan, Y.; Dikicioğlu, E.; Alkanat, M.B.; Ozdemir, N. Primary carcinoid tumor of the ovary-A case report. Acta Oncol. 1992, 31, 790-792. [CrossRef] [PubMed] 